\title{
Celstino Migliore John Paul II. - A Great Communicator of Our Times
}

John Paul II placed the Church on a bushel basket, not under it, in order that it give light so that all men may believe. He brought it to a place of visibility.

Among the many titles by which he was known was that of "showman of God." Never was a Pope more in the media glare than John Paul II. And never before him did a Pope use the media as effectively to convey his message. Someone even coined the phrase: Pontifex massmediaticus ("massmedia pontiff"), recalling an old adage: „The tongue is sharper than the sword."

The use of massmedia in the Church is not some new novelty exclusive to John Paul II. And in this is the guarantee of his authenticity. It goes back to the Gospel, wherein Jesus invited His disciples to go out into the world and to teach all nations. It was an implicit invitation to use all the available instruments to spread the Good News. In fact, He said: that which I have told you in secret, go and preach on the rooftops. This was a precise expression in those times, but one can think of a similar illustration in our day in which our rooftops are covered with antennae and satellite dish in order to get many television channels.

Soon after Jesus, St. Paul did not hesitate to go to the aeropagus of Athens, the most prestigious and exclusive gathering place at that time. Nonetheless, for centuries Popes rarely spoke to the masses. They rather spoke through encyclicals, apostolic letters, and canonical texts. The first pope to be seen on film was Leo XIII, who was filmed in the Vatican Gardens in 1896 , by someone who worked with the Lumière brothers, a few days before the historical overthrow of Paris. The Vatican cinema archives preserves this film and it is interesting to see because one can read on the pope's face his reluctance, almost embarrassment at appearing in front of this rudimentary camera.

Pope Pius XI erected the Vatican radio station, inaugurated by Guglielmo Marconi himself, the inventor of the radio. Pius XII began to give radio messages. The famous address was the one in which he tried to avoid the Second World War, with that famous phrase which made its way around the world: everything is lost with war, everything is possible with peace.

The first Pope to leave the Vatican and board a train to go to the Marian shrine of Loreto was John XXIII. His frequent visits to prisoners, school children, and hospitals, quickly earned him the title of the "Good 
Pope": a human pope, who recognized and wanted to remain close to real human conditions and the most difficult aspects of human life. Magazines immediately seized upon this figure, this image of goodness and humanness. After him, Paul VI made several trips out of Italy: to Uganda, the Philippines, the Holy Land, and the most memorable being his visit to the United Nations in New York in 1965. Television was able to transmit the images all over the world, but the quality was poor, being black and white.

I do not believe that the young Karol Wojtyla ever took courses in social communications. But as a young adult he made his début as an actor and poet. The art of communicating seemed to have been written on his DNA. He then put it to use in service of the Gospel in terms of the Gospel and not simply of pure social communications. This is where the greatness of John Paul II's communication lies.

Beginning from 1990, during the height of technological advances with telephones and television, John Paul II wished that anyone in the world be able to dial a phone number and listen to the message of the pope in various languages. These dealt with excerpts from homilies, discourses, apostolic letters, that are always renewed with the passage of time and that have had a considerable audience, so much so that at times they short-circuit the Vatican telephone lines.

Vatican Radio has kept a record of the Pope's trips: 104 in 129 countries and 144 in various Italian cities and towns, with an impressive number of discourses and homilies.

With his vestments blowing in the wind, his kissing children all over the world, and never afraid of giving or refusing embraces, with sentiments expressed unabashedly, the pope was a great media personality, with a natural disposition of giving to God what belonged to God and to Caesar what belonged to Caesar, even using the things of Caesar.

Certainly, John Paul II knew well the risks of sensationalism associated with great use of the media. One day he said: „We do not know when a word, even one among many, touches the heart of someone." He was not ignorant of the fact that television has its own rules, and to ensure a wider audience, would turn to the spectacular and even a theatrical representation which would overshadow the sense of mystery, and even weaken or annul the concept of the People of God, and of the mystical body, who are essential to the reception of the Christian message. He was aware and not silent of the fact that the mass media could and often does distort reality and the truth about man. He denounced it often and without mincing words. One day, when he was already using a cane to walk, on a long flight he said to the journalists who were accompanying him: "The cane is also used to beat those who are out of line, perhaps even a few journalists." 
At the beginning of his pontificate he introduced himself as a „Pope from afar," because he came from behind the Iron Curtain. But he soon endeared himself to every person in the world, thanks also to his "media genius.“ As the German philosopher Rüdiger Safranski said of him: „The special thing about this pope, this media genius, is that he managed to create a connection between mysticism and the media, between a spiritual approach to life and the media's social packaging and globalization of this phenomenon. This is something new even in the age of television" (Zenit, April 16, 2005).

Before my present assignment here at the United Nations, I worked for seven years in the Secretariat of State in the Vatican. On several occasions I met with the Pope. That which always impressed me was that I never left an encounter with the Pope the same way I went in. His look there was something mystical in his eyes - that always brought me to another level. Even when speaking of situations of war, of misery in the world and we felt powerless in the face of man's malice - from his eyes, from his words came a profound surety that radiated hope to work for peace.

Another dimension of Pope John Paul II that I was able to take with me from my years of collaboration in the Secretariat of State was his meticulous and widespread consultation, the sense of dialogue and debate before making a decision. Above all, when dealing with decisions or taking positions that were not popular, the mass media attributed to him an alleged authoritarianism and centralization. But anyone who was close to him and able to follow the course of many decisions and pronouncements, could instead document a great sense of listening, of consultation, of debate and dialogue. The system of decision-making in the Catholic Church, with regard to its basic fundamentals, does not rest on votes, or the majority, but goes back to consultation and dialogue and John Paul II has certainly made great use of it.

John Paul II was a pope who used every means of transportation. He spoke many languages. He delivered addresses and celebrated Mass in languages such as Arabic, Japanese, Tagallo, Swahili, and others which he did not know or speak. But before every trip he invited a priest for a few days from the Roman curia who knew a particular language to give him a few lessons on how to correctly pronounce his text in the native language and also to learn a couple of expressions, those that came from the heart, for the people whom he would meet.

He was a pope who, over his white cassock, put on jackets, overcoats, and scarves of every kind. He was present at dances and songs of every people and tradition. In the summer, at Castel Gandolfo, he loved to receive in the evening groups of young people or actors, always spontane- 
ous, who would entertain him with music, culture, and with exposure to peoples of the world. He was a pope who sang and cut his own CDs. On the First Saturday of every month he led the Rosary or Vatican Radio. One day I heard a program with various testimonies from truck drivers who said that at nighttime as they were driving they would listen to the pope on the radio and it would elevate their spirits from their mundane routine lives.

Above all, John Paul II knew how to be a Pope of gestures: he had the sense of prophetic gesture, that which moves history. We think of the encounter he had with his would-be assassin in prison: the image of their heads almost touching each other immersed in deep conversation conveyed the profound message of a spokesman of a religion based upon peace and reconciliation.

We also think of his embrace of Rabbi Toaf in his Synagogue of Rome, and the prayer he inserted in the crevice of the Wailing Wall. These moments have revolutionized the rapport between Catholics and Jews. The talk he gave in the Mosque in Damascus with Mufti Kuftaro, and his prayer meetings in Assisi have raised his image as the spiritual leader.

Although, even under this profile, one can say that he lived in a unique moment in history, of ample access to communication technology. We also remember the impact of that image of 22 November 2001, when television cameras showed him seated in front of a computer as he sent via Internet, his apostolic exhortation, Ecclesia in Oceania. He himself stated that the Internet was a new way of spreading the Gospel. The Holy See website - www.vatican.va - is one of the most frequented in the world with an approximate 50 million hits a month.

His specificity, as I said earlier, was having used extensively the logic and modality that were not exactly those of the mass-media, but those of the Gospel. What does this mean? To be Pope means to have and exercise authority, leadership; to be the custodian of a design or plan, to preserve and propose principles and fundamental values of society; to maintain a clear sense of the ends of all things, of one's personal and communitarian life, having a clear vision for oneself. His clear vision as pontiff, as bridge builder, meant to build bridges between man and God, between society and God, around society itself. He did not use mass communication for virtual reality but for reality. He kept communication at the service of a truth which every day assumes a new and creative face, because it is incarnated in conditions that change, but it is not man-made, because it is totally dependent upon God, it is illumined, guided and purified by the wisdom of God.

In a time of ephemeral values and ideological crises, he was a firm 
point of reference, a moral authority. In his many topics - in particular with regard to questions of life, family, personal rights and freedom, one could accept them and follow them, or criticize them and not share them, but he was loved because he said what he believed and believed what he said. A journalist once said: of his ten fingers, Pope John Paul II used nine to preach the Gospel and one to govern the Church.

In the last years of his pontificate one saw the decline of a strong pope, full of energy, athletic, to a pope who gradually became fragile, sickly, to the point where he could not move or express himself as before. And yet he continued to fascinate those who followed him, those who met him, those who listened to him.

For more than 26 years he kept us focused on the subtle frontier between the transcendent and the here and now, a fine line that is often blurred in daily life. His long agony confirmed in a powerful way this very message. We witnessed an apparently helpless man who was telling us that no moment of our lives is without value or meaning if we constantly focus on laying down our lives for others.

After having shown God to the world in all his venues and situations, he was not ashamed to also show a crucified Lord. The wisdom of the cross is a folly to the world and in particular for the mass-media.

His last letter directed to those in social communications, in light of the World Communications Day, was published in February, at a time when he was completely losing his ability to speak, his prime instrument of evangelization.

It is normal to ask, after having made such great use of the media, what impact did John Paul II have on it? And what? Experts are better at analyzing this. For my part, I would like to offer an impression that has made its way during the impressive media coverage of the death and funeral of John Paul II. In the last hours of his agony, and in the week following his death, it seemed to me that the newspapers and television captured one of the fundamental characteristics of communication employed by the pope. For entire days we were able to enjoy telecasts of high quality on the legacy of the pope. In a particular way, the media adopted a positive memory, the evangelical memory of the Magnificat that puts everything in a positive and constructive perspective, recognizing the best in a person and all the dimensions of his works, including the transcendent.

Perhaps it is precisely in this last part of his pontificate, the so-called "weak" part (in the sense of his physical debilitation), that the pope had his major impatt on the mass-media. By living with faith his weakened condition, and human helplessness, he upset the utilitarian criteria of usefulness, of beauty and strength at all costs - properties of the media. 
He no longer was able to speak a clear and strong word; his facial muscles did not respond readily to his sentiments; his mobility was restricted to a few uncertain steps; nonetheless, he continuled to communicate a great sense of paternity and moral authority, which never diminish, even in poor health.

The great communicator Pope departed with gratitude to the massmedia and journalists. In his last page of his will and testament he wrote: „How can I not embrace with great memory? the representatives of the means of social communication."

It is somewhat unusual for a Pope to include such a mention in his last will and testament, but we are not surprised to find it in John Paul II's last will. This personal and final acknowledgment of a powerful medium which he chose as a priority and used to live out the missionary dimension of his papacy is encapsulated in his namesake: John Paul.

(Speech by Archbishop Celestino Migliore, Apostolic Nuncio, Permanent Observer of the Holy See to the United Nations, on World Communications Day May 14, 2005, at Pauline Books \& Media Center New York) 